\title{
Studi Eksperimental Penambahan Limbah Bubut Sebagai Bahan Subtitusi Parsial Agregat Halus Terhadap Kuat Tekan Beton
}

\author{
Puja Nifta Hadi ${ }^{1}$ dan Agustinus Agus Setiawan ${ }^{2 *}$ \\ ${ }^{1}$ Program Studi Teknik Sipil, Fakultas Teknologi dan Desain, Universitas Pembangunan Jaya, \\ Tangerang Selatan, Indonesia \\ ${ }^{2}$ Center for Urban Studies, Universitas Pembangunan Jaya, Tangerang Selatan, Indonesia, \\ agustinus@upj.ac.id
}

\begin{abstract}
This study has an objective to determine the effect of lathe waste addition to compressive strength of concrete. The lathe waste added as a partial substitution of fine aggregate, the lathe waste used in this experiment is the one retained on sieve number $200(0,075 \mathrm{~mm})$. The sample used in this study is cylindrical concrete specimens with diameter $150 \mathrm{~mm}$ and height $300 \mathrm{~mm}$. Concrete mixtures that given partial materials of lathe waste vary from $0 \%, 5 \%, 10 \%, 15 \%$ and $20 \%$. The result of this study shows that as the percentage of lathe waste increased, the compressive strength has a downward trend. Addition of lathe waste decreased the compressive strength of concrete up to $64,21 \%$.
\end{abstract}

Keywords : concrete, lathe waste, compressive strength

\begin{abstract}
Abstrak : Penelitian ini bertujuan untuk mengetahui pengaruh penambahan limbah mesin bubut terhadap kuat tekan beton. Limbah mesin bubut ditambahkan secara parsial untuk menggantikan agregat halus, di mana limbah mesin bubut yang digunakan adalah yang tertahan pada saringan nomor 200. Sampel pada penelitian ini berbentuk silinder beton dengan ukuran diameter $150 \mathrm{~mm}$ dan tinggi $300 \mathrm{~mm}$. Campuran beton yang diberikan bahan parsial serpihan aluminium bervariasi mulai dari $0 \%, 5 \%, 10 \%, 15 \%$, dan 20\%. Hasil pengujian menunjukan bahwa semakin bertambahnya persentase parsial limbah mesin bubut, kuat tekan beton juga cenderung menurun. Penambahan limbah mesin bubut ini dapat menurunkan kuat tekan beton hingga $64,21 \%$.
\end{abstract}

Kata Kunci : beton, limbah mesin bubut, kuat tekan

\section{PENDAHULUAN}

Salah satu kebutuhan manusia di bidang infrastruktur adalah berupa konstruksi bangunan gedung. Konstruksi bangunan gedung memiliki beberapa komponen penting, seperti struktur bawah, struktur tengah, dan struktur atas. Struktur bangunan merupakan salah satu faktor terpenting dalam konstruksi, karena dikaitkan dengan keamanan penggunaannya, sehingga diperlukan kualitas struktur yang kuat dan efisien. Struktur juga dapat mendukung keberadaan komponen non-struktur, seperti façade, interior, dan detail arsitektur.

Salah satu material atau bahan konstruksi yang jamak digunakan di bidang konstruksi adalah material beton bertulang. Teknologi beton sedang dikembangkan hari demi hari, sehingga ada lebih banyak inovasi untuk meningkatkan kualitas beton. Akhir-akhir ini, banyak bahan yang digunakan untuk menjadi pengganti campuran beton normal. Substitusi bahan tersebut ke dalam campuran beton diharapkan mampu memperbaiki sifat-sifat mekanis dari beton. Salah satu bentuk limbah padat yang diperkirakan dapat menggantikan bahan penyusun beton, adalah limbah mesin bubut.

Bengkel bubut adalah bisnis yang bergerak di bidang otomotif. Bengkel bubut menghasilkan limbah logam atau besi dari mesin yang diperbaiki. Limbah ini merupakan hasil dari pengikisan mesin yang diperbaiki, menghasilkan serpihan logam atau besi yang halus. Sampah dibuang begitu saja, tanpa ada yang memanfaatkannya. Gambar 1 menunjukkan limbah dari proses pekerjaan pembubutan besi. Dari hasil pengamatan visual limbah ini memiliki kemiripan dengan agregat ringan dalam beton, yang biasanya diisi oleh pasir alam. 


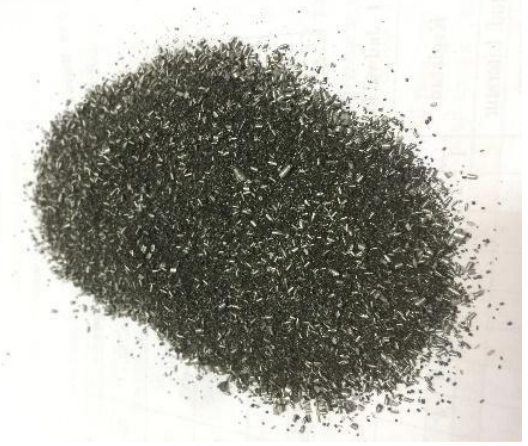

Gambar 1. Limbah Bubut Besi

Penelitian mengenai pengaruh penambahan limbah bubut pada beton dilakukan oleh Kumaran et.al. [1], pada penelitian ini tersebut limbah bubut ditambahkan secara bervariasi, yaitu sebanyak $1 \%, 1.5 \%$, dan $2 \%$ dari total berat beton. Hasil penelitian ini menunjukkan adanya peningkatan kuat tekan hingga $11.25 \%$ pada sampel dengan limbah bubut sebanyak $1.5 \%$. Selain itu pada uji kuat tarik belah beton dengan campuran limbah bubut mengalami peningkatan hingga $14.75 \%$, dan $18 \%$ pada uji kuat lentur.

Sementara itu Firdous et.al. [2] melakukan penelitian tentang analisis karakteristik kekuatan beton bertulang dengan serpihan limbah mesin bubut dan lumpur dari pengolahan limbah industri, atau effluent treatment plant (ETP). Lumpur yang digunakan diambil dari hasil pengolahan limbah titania atau titanium dioksida $\left(\mathrm{TiO}_{2}\right)$. Lumpur tersebut akan digunakan untuk menggantikan agregat halus secara parsial, dengan persentase $0 \%$, $6 \%, 12 \%, 18 \%$, dan $24 \%$ dari berat agregat halus, disertai penambahan limbah mesin bubut sebanyak $2 \%$ dari berat agregat halus. Hasil dari penelitian menunjukkan bahwa kuat tekan maksimum diperoleh pada sampel dengan $12 \%$ lumpur ETP, dan kuat tarik belah maksimum diperoleh oleh sampel dengan 18\% lumpur ETP.

\section{Formulasi Masalah}

Pasir alam sebagai bahan penyusun campuran beton, merupakan bahan yang lama kelamaan akan habis. Oleh karena itu perlu dipikirkan alternatif penggunanan bahan lain untuk menggantikan fungsi pasir alam ini. Dalam hal ini limbah bubut besi yang memiliki kemiripan visual serupa dengan pasir alam, memungkinkan untuk digunakan sebagai bahan pengganti pasir dalam campuran beton.

\section{Batasan Masalah}

Dalam penelitian ini batasan masalah yang diambil adalah kuat tekan beton yang direncanakan $\left(f_{c}\right.$ ') sebesar $25 \mathrm{MPa}$, semen yang digunakan Portland tipe 1. Pengujian kuat tekan menggunakan benda uji silinder berdiameter $15 \mathrm{~cm}$ dan tinggi $30 \mathrm{~cm}$ pada umur beton 7 hari, 14 hari dan 28 hari.

Limbah bubut yang digunakan yang tertahan di saringan $0,075 \mathrm{~mm}$ (saringan no. 200) dengan persentase berat yaitu; $0 \%$; $5 \% ; 10 \% ; 15 \%$ dan $20 \%$.

\section{Tujuan}

Penelitian dilakukan dengan metode eksperimental dengan tujuan untuk mengetahui pengaruh penambahan limbah bubutan besi sebagai substitusi parsial agregat halus pada beton terhadap kuat tekan beton.

\section{KAJIAN PUSTAKA}

Beton adalah merupakan material komposit yang terbentuk dari pencampuran semen Portland, agregat halus, agregat kasar, dan air yang fungsinya sebagai pereaksi kimia antara semen dan air yang membuat campuran mengeras.

\section{Bahan Penyusun Beton}

Agregat adalah istilah kolektif untuk bahan mineral seperti pasir, kerikil, dan batu pecah yang digunakan dengan media pengikat (seperti air, aspal, semen Portland, kapur, dan sebagainya). Untuk membentuk bahan campuran (misalnya beton aspal bitumen dan beton). Agregat sebagai salah satu bahan penyusun beton memiliki fungsi untuk mengurangi susut beton dan mempengaruhi nilai keekonomisan beton.

Semen Portland adalah salah satu media pengikat yang menyatukan agregat halus dan agregat kasar menjadi massa 
padat melalui proses hidrasi. Semen Portland adalah semen hidrolik yang diproduksi dengan menggiling terak semen Portland, terdiri dari kalsium silikat hidrolik, yang digiling bersama dengan beberapa bahan lainnya.

Air adalah bahan yang diperlukan agar beton bereaksi dengan semen Portland. Air digunakan untuk melarutkan semen menjadi pasta, yang kemudian mengikat semua agregat, dari agregat halus hingga agregat kasar.

\section{Limbah Bubut}

Sampah merupakan masalah yang perlu mendapat perhatian untuk mengatasinya. Upaya pengelolaan sampah di masyarakat masih belum maksimal, dengan limbah yang ada sekitar. Pengelolaan limbah harus segera diperbaiki karena memiliki dampak negatif terhadap masyarakat di masa depan. Limbah bubut adalah bahan dari mesin bubut, yang dapat digunakan sebagai serat besi [4]. Bengkel bubut memperbaiki mesin yang rusak akan menghasilkan limbah yang terkelupas.

\section{Kekuatan Tekan}

Kekuatan tekan adalah kapasitas maksimum suatu material untuk menahan beban per unit area [1]. Kekuatan tekan beton normal umumnya berkisar antara 20 $40 \mathrm{MPa}$. Kekuatan beton dipengaruhi oleh rasio semen air, jenis agregat, kemampuan kerja, curing, dan usia beton. Untuk mendapatkan beton dengan kekuatan yang diinginkan, beton perlu dirawat dengan baik pada usia dini, sehingga proses hidrasi berjalan dengan sempurna. Uji kuat tekan dilakukan dengan mesin uji tekan (UTM) dengan menempatkan sampel silinder berdiameter $150 \mathrm{~mm}$, dan tinggi $300 \mathrm{~mm}$ secara tegak lurus dan diberi beban tekan secara bertahap hingga objek sampel runtuh. Tes ini memperoleh beban maksimum yang bisa dipegang oleh sampel hingga runtuh. Kekuatan tekan beton dapat dihitung dengan membagi beban maksimum dengan luas permukaan silinder sampel, atau secara matematis ditulis sebagai:

$$
f_{c}^{\prime}=\frac{P}{A}
$$

dengan,

$f^{\prime}{ }_{c} \quad=$ kuat tekan, $\mathrm{MPa}$

$P \quad=$ beban maksimum, $\mathrm{N}$

$A \quad=$ luas permukaan sampel, $\mathrm{mm}^{2}$

Sesuai dengan Peraturan Beton Indonesia 1971, ada standar kekuatan tekan beton sesuai dengan usia beton. Standar tersebut dapat dilihat pada Tabel 1 di bawah ini.

Tabel 1. Korelasi Umur dan Kuat Tekan Beton

\begin{tabular}{cc}
\hline $\begin{array}{c}\text { Usia Beton } \\
\text { (Hari) }\end{array}$ & $\begin{array}{c}\text { Kuat Tekan } \\
\text { Beton } \\
(\mathbf{\%})\end{array}$ \\
\hline $\mathbf{3}$ & 40 \\
\hline $\mathbf{7}$ & 65 \\
\hline $\mathbf{1 4}$ & 88 \\
\hline $\mathbf{2 1}$ & 95 \\
\hline $\mathbf{2 8}$ & 100 \\
\hline $\mathbf{5 6}$ & 112,4 \\
\hline
\end{tabular}

\section{METODOLOGI PENELITIAN Material}

Material yang digunakan dalam penelitian ini adalah :

1. Semen, merk Tiga Roda

2. Agregat kasar, dari Cigudeg

3. Agregat halus, dari Sumedang

4. Air, dari sumber PDAM

5. Limbah sisa proses bubut besi

Agregat yang akan digunakan harus sesuai dengan standar yang digunakan, sehingga dilakukan pengujian untuk melihat kesesuaian bahan. Hasil tes dapat dilihat pada Tabel 2

Tes analisis ayakan dilakukan untuk mengetahui gradasi agregat halus, agregat kasar, dan limbah bubut. Hasil pengujian gradasi terhadap ketiga material tersebut ditunjukkan pada Gambar 2, 3 dan 4. Dari hasil pengujian nampak bahwa material memenuhi kriteria gradasi yang disyaratkan 
Tabel 2. Sifat Fisik Material

\begin{tabular}{|c|c|c|c|}
\hline Agregat & Tes & Hasil & Standard \\
\hline \multirow{5}{*}{$\begin{array}{c}\text { Agregat } \\
\text { Kasar }\end{array}$} & $\begin{array}{l}\text { Modulus } \\
\text { Kehalusan }\end{array}$ & 7,09 & $3,0-8,0$ \\
\hline & $\begin{array}{l}\text { Spesific } \\
\text { Gravity }\end{array}$ & $\begin{array}{c}2,56 \\
\mathrm{gr} / \mathrm{cm}^{3}\end{array}$ & $\begin{array}{c}2,2-2,7 \\
\mathrm{gr} / \mathrm{cm}^{3}\end{array}$ \\
\hline & Berat Jenis & $\begin{array}{c}1,53 \\
\mathrm{gr} / \mathrm{cm}^{3}\end{array}$ & $\begin{array}{c}>1,2 \\
\mathrm{gr} / \mathrm{cm}-3-\end{array}$ \\
\hline & Absorpsi & $2,75 \%$ & \\
\hline & $\begin{array}{l}\text { Kadar } \\
\text { lumpur }\end{array}$ & $0,68 \%$ & $<1 \%$ \\
\hline \multirow{5}{*}{$\begin{array}{c}\text { Agregat } \\
\text { Halus }\end{array}$} & $\begin{array}{l}\text { Modulus } \\
\text { Kehalusan }\end{array}$ & 2,67 & $1,5-3,8$ \\
\hline & $\begin{array}{l}\text { Spesific } \\
\text { Gravity }\end{array}$ & $\begin{array}{c}2,52 \\
\mathrm{gr} / \mathrm{cm}^{3}\end{array}$ & $\begin{array}{c}2,2-2,7 \\
\mathrm{gr} / \mathrm{cm}^{3}\end{array}$ \\
\hline & Berat Jenis & $\begin{array}{c}1,51 \\
\mathrm{gr} / \mathrm{cm}^{3}\end{array}$ & $\begin{array}{c}>1,2 \\
\mathrm{gr} / \mathrm{cm}^{3}\end{array}$ \\
\hline & Absorpsi & $2,47 \%$ & \\
\hline & $\begin{array}{l}\text { Kadar } \\
\text { lumpur }\end{array}$ & $2,75 \%$ & $<5 \%$ \\
\hline
\end{tabular}

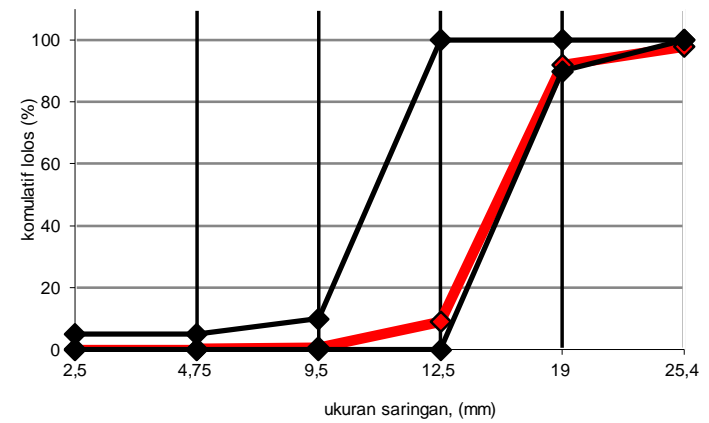

Gambar 2. Gradasi Agregat Kasar

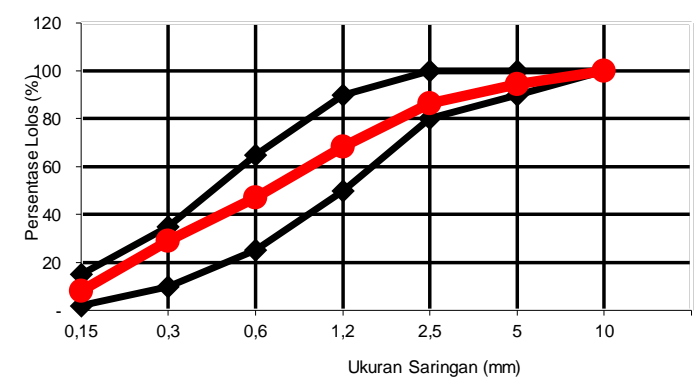

Gambar 3. Gradasi Agregat Halus

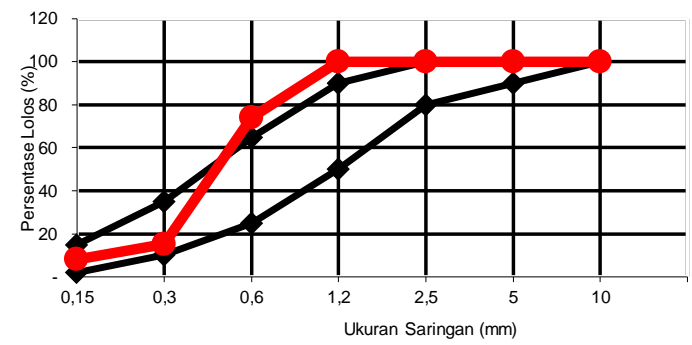

Gambar 4. Gradasi Limbah Bubut Besi

\section{Desain Campuran Beton}

Berdasarkan hasil uji material yang ditunjukkan pada Tabel 2, desain campuran untuk campuran beton dapat dihitung. Standar yang digunakan adalah SNI 03 2834 - 2000 tentang prosedur pembuatan beton normal. Kekuatan tekan yang ditentukan $\left(f{ }_{c}{ }_{c}\right)$ diatur menjadi $25 \mathrm{MPa}$. Dalam penelitian ini, ada 5 jenis komposisi beton, yang disebut sebagai $\mathrm{AB} 1$ untuk sampel kontrol, AB2 untuk substitusi parsial 5\% agregat halus, $\mathrm{AB} 3$ untuk substitusi parsial 10\% agregat halus, AB4 untuk substitusi parsial $15 \%$ dari fine agregat, AB5 untuk substitusi parsial $20 \%$ dari agregat halus. Komposisi campuran ditunjukkan pada Tabel 3.

\section{Benda Uji}

Untuk menentukan kekuatan tekan beton limbah bubut, maka dibuat beberapa spesimen. Benda uji yang digunakan adalah beton berbentuk silinder, berukuran diameter $150 \mathrm{~mm}$ dan tinggi $300 \mathrm{~mm}$. Beton yang mengeras kemudian dikeluarkan dari cetakan dan ditempatkan adalah tangki curing untuk proses curing. Gambar 5 menunjukkan proses pembuatan benda uji dan proses curing.

Tabel 3: Komposisi Material Penyusun Beton per $\mathrm{m}^{3}$

\begin{tabular}{cccccccc}
\hline $\begin{array}{c}\text { Kode } \\
\text { Benda Uji }\end{array}$ & Air & Semen & $\begin{array}{c}\text { Agregat } \\
\text { Kasar }\end{array}$ & \multicolumn{2}{c}{ Pasir } & \multicolumn{2}{c}{ Limbah Bubut } \\
\cline { 2 - 8 } & $(\mathrm{kg})$ & $(\mathrm{kg})$ & $(\mathrm{kg})$ & $(\mathrm{kg})$ & $\%$ & $(\mathrm{~kg})$ & $\%$ \\
\hline AB1 & 183,16 & 469 & 806,4 & 816,63 & $100 \%$ & 0 & $0 \%$ \\
\hline AB2 & 183,16 & 469 & 806,4 & 775,799 & $95 \%$ & 40,8 & $5 \%$ \\
\hline AB3 & 183,16 & 469 & 806,4 & 734,967 & $90 \%$ & 81,7 & $10 \%$ \\
\hline AB4 & 183,16 & 469 & 806,4 & 694,136 & $85 \%$ & 122,5 & $15 \%$ \\
\hline AB5 & 183,16 & 469 & 806,4 & 653,304 & $80 \%$ & 163,3 & $20 \%$ \\
\hline
\end{tabular}




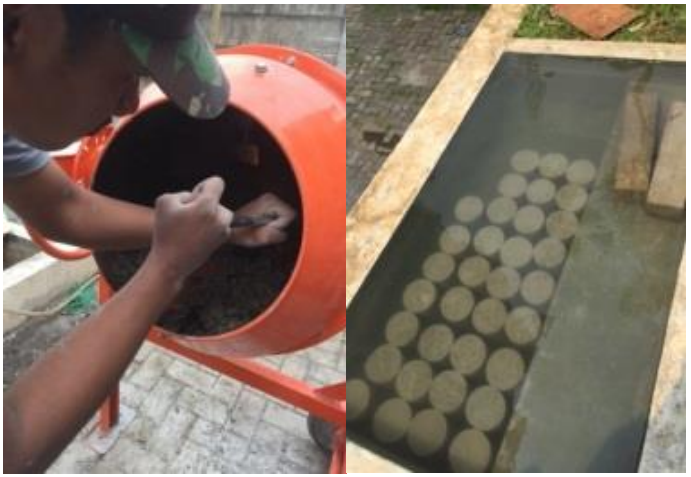

Gambar 5. Pembuatan Benda Uji dan Proses Curing

\section{Metode Pengujian}

Uji kuat tekan dilakukan sesuai dengan SNI 1974 - 2011 tentang metode uji kuat tekan untuk spesimen silindris. Beton diuji dengan mesin uji universal (UTM) pada usia 7 hari, 14 hari, dan 28 hari.

\section{HASIL PENELITIAN DAN ANALISIS Tes Slump}

Beton segar juga diuji dengan uji slump. Uji slump dilakukan untuk menentukan konsistensi dan kemampuan kerja campuran beton. Dalam penelitian ini, nilai slump yang ditargetkan adalah $8 \pm 2$ $\mathrm{cm}$. Hasil uji slump campuran beton dapat dilihat pada Tabel 4.
Tabel 4. Hasil Uji Nilai Slump

\begin{tabular}{ccc}
\hline Benda Uji & $\begin{array}{c}\text { Limbah } \\
\text { Bubut, \% }\end{array}$ & Slump (cm) \\
\hline AB1 & $0 \%$ & 7,5 \\
\hline AB2 & $5 \%$ & 7,1 \\
\hline AB3 & $10 \%$ & 7 \\
\hline AB4 & $15 \%$ & 6,9 \\
\hline AB5 & $20 \%$ & 6,7 \\
\hline
\end{tabular}

Berdasarkan hasil uji slump, nilai slump dari kelima benda uji masih masuk dalam nilai slump rencana yaitu $8 \pm 2 \mathrm{~cm}$. Dari hasil ini menunjukkan bahwa semakin meningkatnya kadar limbah bubut besi dalam campuran, akan menunjukkan penurunan nilai slump. Penurunan ini mempengaruhi lama atau waktu untuk pencampuran beton segar hingga menjadi campuran yang homogen.

\section{Kuat Tekan}

Hasil uji kuat tekan beton pada umur 7, 14 dan 28 hari ditunjukkan pada Tabel 5.

Tabel 5. Hasil Uji Kuat Tekan Beton

\begin{tabular}{cccc}
\hline Benda & \multicolumn{3}{c}{ Kuat Tekan (MPa) } \\
\cline { 2 - 4 } Uji & 7 hari & 14 hari & 28 hari \\
\hline AB1 & 17.0 & 22.0 & 27.1 \\
\hline AB2 & 4.9 & 9.0 & 11.7 \\
\hline AB3 & 3.0 & 5.6 & 9.4 \\
\hline AB4 & 3.7 & 5.0 & 9.7 \\
\hline AB5 & 3.7 & 5.0 & 9.7 \\
\hline
\end{tabular}

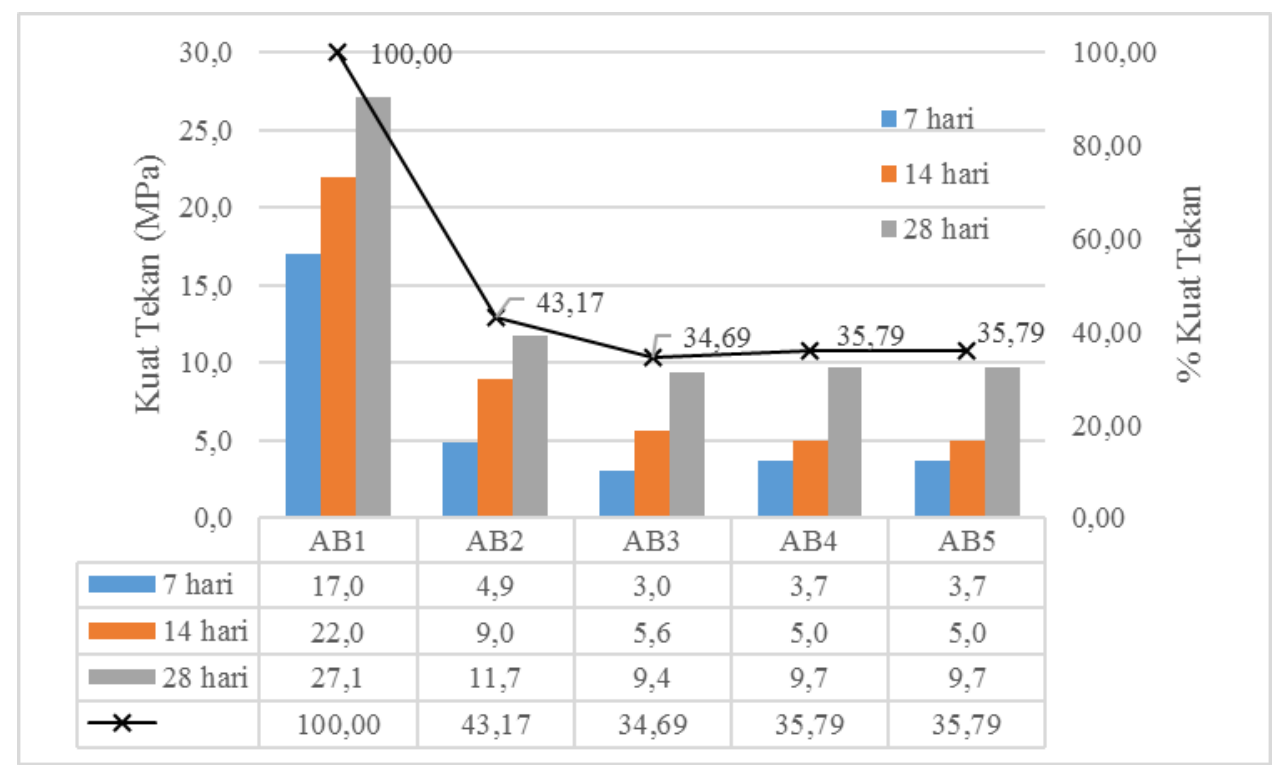

Gambar 6. Pertumbuhan Kuat Tekan Beton 
Dari Gambar 6 dapat dilihat bahwa kuat tekan untuk spesimen beton normal atau AB1 meencapai kekuatan tekan yang ditentukan. Sedangkan untuk spesimen beton yang menggunakan limbah sisa bubut sebagai agregat halus menunjukkan penurunan kuat tekan beton pada umur 28 hari. Pada penggantian pasir dengan limbah bubut besi kuat tekan yang dihasilkan pada 28 hari hanya sebesar $43,17 \%$ dari target kuat tekan rencana. Semakin banyak penggunaan limbah bubut besi menunjukkan penurunan kuat tekan yang makin besar. Faktor utama yang menyebabkan penurunan kuat tekan beton limbah bubut adalah reaksi kimia yang terjadi antara limbah bubut dan semen Portland. Secara visual kejadian ini dapat diamati saat beton segar telah dituang dalam cetakan, beton mengalami pengembangan volume dan membentuk beberapa gelembung udara, yang menyebabkan porositas pada beton. Rongga ini kemudian menyebabkan penurunan kuat tekan beton, karena beton tidak padat.

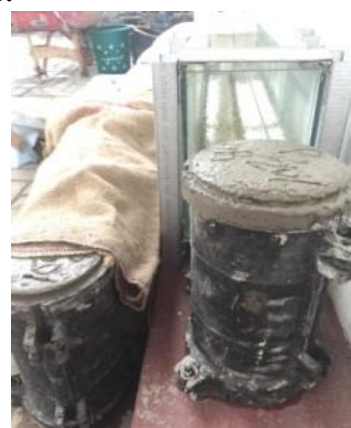

Gambar 7. Beton Yang Mengembang Dalam Cetakan

Berdasarkan grafik di atas, jika dibandingkan dengan beton limbah bubut, nilai kuat tekan tertinggi dicapai oleh $\mathrm{AB} 2$, dengan substitusi parsial 5\% agregat halus, yang setara dengan 16,4 MPa. Kekuatan tekan terendah dicapai oleh $\mathrm{AB} 4$, dengan kekuatan tekan sama dengan 9,6 $\mathrm{MPa}$ dengan substitusi limbah bubut $15 \%$.

Hasil ini dari limbah beton bubut tidak dapat dikategorikan atau digunakan sebagai beton struktural. Dalam SNI 2847 - 2013, diperlukan bahwa beton struktural harus memiliki kuat tekan tertentu minimal 17 MPa. Namun, beton sisa bubut masih bisa digunakan sebagai beton non struktural. Beton non-struktural dengan kekuatan tekan di bawah $17 \mathrm{MPa}$, dapat diproduksi tanpa pengawasan khusus, hanya terbatas pada pengawasan kualitas material yang ringan. Dalam penelitian ini, substitusi parsial dilakukan dengan persentase besar, yaitu berkisar 5 - $20 \%$.

\section{SIMPULAN}

Berdasarkan analisis hasil pengujian, dapat disimpulkan bahwa penambahan limbah bubut sebagai bahan pengganti parsial agregat halus pada beton dapat mempengaruhi sifat fisik, mekanik dan kimia. Efek dari penambahan limbah bubut sebagai pengganti parsial agregat halus adalah:

1. Kekuatan tekan beton tertinggi dengan penambahan limbah bubut dicapai oleh AB2 dengan campuran 5\% dengan kekuatan tekan 11,7 MPa. Dengan hasil ini, beton limbah bubut tidak dapat digunakan sebagai beton struktur yang memiliki persyaratan minimum $20 \mathrm{MPa}$.

2. Beton dengan pengganti limbah bubut memiliki kekuatan tekan di bawah 17 $\mathrm{MPa}$, menunjukkan bahwa beton masih dapat digunakan sebagai beton nonstruktural.

Untuk penelitian berikutnya, dalam campuran beton dengan limbah bubut besi sebagai pengganti pasir, dimungkinkan untuk menambahkan bahan lain yang memiliki sifat untuk meningkatkan kuat tekan beton, seperti abu terbang, abu sekam padi atau bahan tambah kimiawi lainnnya.

\section{DAFTAR PUSTAKA}

1. M., Kumaran, M., Nithi, dan Reshma $\mathrm{K}$., Effect of Lathe Waste in Concrete as Reinforcement, International Journal of Research in Advent Technology, Special Issue, pp. $78-83$, 2015. 
2. Firdous, Suhaib, dan Mohit, Bajaj, Strength Characteristics Analysis of Concrete Reinforced with Lathe Machine Scrap and ETP Sludge, International Journal of Latest Research in Engineering and Computing. Vol. 5, No. 3, pp. $61-66$, 2017.

3. Badan Standarisasi Nasional, SNI 1974:2011. "Cara Uji Kuat Tekan Beton Dengan Benda Uji Silinder", 2011.

4. Sudjati, J J, Yuliyanti T, Rikardus, Pengaruh Penggunaan Serbuk Kaca Sebagai Bahan Substitusi Agregat Halus, Jurnal Teknik Sipil, Vol. 13 No.1 Page 1-11, 2014.

5. Suhartini, A, Gunarti A.S., Hasan A., Pengaruh Penambahan Tumbukan Limbah Botol Kaca Sebagai Bahan Subtitusi Agregat Halus Terhadap Kuat Tekan Dan Kuat Lentur Beton, Jurnal Bentang, Vol. 2 No.1, pp 66-80, 2014.

6. Paryati, N, Kuat Tekan Beton Dengan Penambahan Serbuk Besi Dan Baja, Jurnal Bentang, Vol.3 No. 1 Universitas Islam 45, 2015.

7. Fadli, Mad W, Studi Eksperimental Pengaruh Penambahan Serat Limbah Banner dan Granulated Blast Furnance Slag Tehradap Kuat Tekan Dan Tarik Belah Beton, Skripsi Universitas Pembangunan Jaya, 2017.

8. Arikunto, S. , Prosedur Penelitian Suatu Pendekatan Praktek, Jakarta: Penerbit Rineka Cipta, 2010.

9. Badan Standarisasi Nasional, SNI 032834-2000 "Tata Cara Pembuatan Rencana Campuran Beton Normal", 2000.

10. Badan Standarisasi Nasional, SNI 152049: "Semen Portland", 2004.

11. Badan Standarisasi Nasional, SNI 1969:2008. "Cara Uji Berat Jenis dan
Penyerapan Air Agregat Kasar", 2008.

12. Badan Standarisasi Nasional, SNI 034804-1998. "Metode Pengujian Bobot Isi dan Rongga Udara Dalam Agregat”, 1998.

13. Badan Standarisasi Nasional, SNI 034142-1996 "Metode Pengujian Jumlah Bahan Dalam Agregat Yang Lolos Saringan No. 200 (0,075 mm)”, 1996.

14. Badan Standarisasi Nasional, SNI 031968-1990. "Metode Pengujian Analisis Saringan Agregat Halus dan Kasar", 1990.

15. Badan Standarisasi Nasional, SNI 1970:2008. "Cara Uji Berat Jenis dan Penyerapan Air Agregat Halus", 2008.

16. Badan Standarisasi Nasional, SNI 1972. "Cara Uji Slump Beton”, 2008.

17. Badan Standarisasi Nasional, SNI 036817-2002. "Metode Pengujian Mutu Air Untuk Digunakan Dalam Beton”, 2002.

18. Dwi, Maria, Pengenalan Dasar Konstruksi Beton Siku dan Pracetak, TAKA Publisher, Yogyakarta, 2014. 